\title{
Trend Analyses of Critical Values Obtained for Maximum Energy Consumption Ratio Achievable in Ubicomp MANETs Using Location-Aware Transmission Strategies.
}

\author{
M. Kaleem GALAMALI, Assoc. Prof Nawaz MOHAMUDALLY
}

\begin{abstract}
Location-tracking, ubicomp functionalities and MANET transmission strategies are subject to quite promising research [1-51]. It still remains that the worthwhile merging of these fields has a lot to undergo. One key factor over which success of this merging is based is correct protocol design approaches. In the current era of technology, such approaches are alleged as heuristic in nature and hence are unsuitable for implementation [89]. Fine-tunings in middleware services and network architecture reforms are also expected $[90,91]$.
\end{abstract}

A significantly better elaborated objective following such technological progress would be achieving realism in design and evaluation of wireless routing protocols [92]. The output of such studies will also be more suitable for studies in predictability in ubicomp. "Realism" is slow progressing since it creeps in every feature related to ubicomp. One such feature was scrutinised in a previous paper [20] to assess the trend of Maximum Energy Consumption Ratio (Max_R) readable for CBRs under different sets of node densities in ubicomp environments. This study was supported by the corresponding study of trends for each Max_R parameter of equations [36].

To take in "realism" in knowledge of these trends, in this paper, the next probing needed is put forward as: "What are observable critical values in Max_R trends over varying node densities and trends of such critical values?"

Such knowledge will step by step lead to the design of more realistic ubicomp scenarios which are better suited for more worthy testing of newly designed middleware components and communication protocols. This paper remains a follow-up of previous investigations [1-51].

Key terms: Ubicomp- Ubiquitous Computing, MAUCMobile and Ubiquitous Computing, Max_R- Maximum Energy Consumption Ratio, CBR- Constant Bit Rate, MANET- Mobile Adhoc Network, CV- Critical Value.

M. Kaleem GALAMALI,

University of Technology Mauritius (student)

Mauritius

Assoc. Prof Nawaz Mohamudally

University of Technology Mauritius,

Mauritius

\section{Introduction}

Use of MANETs is praised as a valuable solution to meagrely provisioned ubicomp topographies. In
MANETs, energy consumption load is distributed among contributing nodes; this is drastically affected by node densities. A recent study [20] was targeted at finding the trends observable for metric Max_R for node densities varying between 7 until 56. The model suggested in that paper [20] was split into three:

- For node numbers 7 until 25, the exponential model was observed of form:

$$
G(x)=a * \exp (b *(x-1.0))+c
$$

- For node numbers 26 onwards, previous to the peak value observed, tendency is linear of form:

$$
F(x)=d * x+f
$$

- For node numbers 26 onwards, as from the peak value onwards, tendency is exponential of form:

$G(x)=a * \exp (b *(x-2.0))+c$

Following this study, another study [36] was conducted to model mathematically the trends of the six parameters observed above; the sixth parameter being $\mathrm{k}$, representing the value of node number where applicable equation changes from first to third equation above. The results obtained will serve towards better understanding of the evolution and predictability of ubicomp environments. With such progresses happening crawlingly, designers will produce more solemn platforms of realistic simulation scenarios over which testing functionalities for newly built components, including communication protocols and middleware functions, can be efficiently executed.

The probing now required for metric Max_R is the identification of observable critical value obtained during experimentations and formulation of corresponding theoretical trend of such critical values over varying node densities. Four such critical values were observed.

The key contribution of this paper is the establishment of the trends of variations for each of the four critical values observed for metric Max_R introduced previously $[20,36]$ covering node numbers 7 until 56. Such information should mandatorily be presented in an appropriate order so as to unimpedingly assist ubicomp designers to understand the evolution and predictability of ubicomp behaviour and provision for 
Proc. of the Seventh International Conference On Advances in Computing, Electronics and Electrical Technology - CEET 2017. Copyright $(C$ Institute of Research Engineers and Doctors. All rights reserved. ISBN: 978-1-63248-126-9 doi: 10.15224/ 978-1-63248-126-9-25

better suitable simulation scenarios over which novel communication protocols could be tested. The rest of this paper is organised as follows: section 2- Max_R Critical Values, section 3- Critical Values Trend Analyses- Metric Max_R, section 4- Conclusion and References.

\section{Max_R Critical Values.}

2.0 Critical Values Identified.

Four critical values have been identified as follows: Column headings are: $\mathrm{C} 1 \rightarrow$ Max_R CV, C2 $\rightarrow$ Meaning of Max_R CV, C3 $\rightarrow$ Corresponding figure number for the Max_R CV.

\begin{tabular}{|c|l|c|}
\hline C1 & C2 & C3 \\
\hline 1 & Minimum value of Max_R & 1 \\
\hline 2 & \%CBR at modal value of Max_R & 2 \\
\hline 3 & Second modal value of Max_R & 3 \\
\hline 4 & \%CBR at second modal value of Max_R & 4 \\
\hline
\end{tabular}

Table 1: Max_R Critical Values

\subsection{Experimental Critical Values Obtained.}

The values obtained during experiments have been summarised below. Values have been rounded to a maximum of 9 decimal places. Column heading NN $\rightarrow$ Node Number.

\begin{tabular}{|c|c|c|c|c|c|}
\hline NN & CV1 & CV2 & CV3 & CV4 \\
\hline 7 & 1.0 & 44.555555556 & 2.0 & 22.079365079 \\
\hline 8 & 1.0 & 37.312957657 & 2.0 & 18.990767272 \\
\hline 9 & 1.0 & 35.365079365 & 2.0 & 18.603174603 \\
\hline 10 & 1.0 & 27.920634921 & 2.0 & 16.904761905 \\
\hline 11 & 1.0 & 25.904761905 & 2.0 & 17.507936508 \\
\hline 12 & 1.0 & 25.135135135 & 2.0 & 16.740858506 \\
\hline 13 & 1.0 & 23.444444444 & 2.0 & 17.174603175 \\
\hline 14 & 1.0 & 22.126984127 & 2.0 & 16.666666667 \\
\hline 15 & 1.0 & 20.777777778 & 2.0 & 15.666666667 \\
\hline 16 & 1.0 & 20.015873016 & 2.0 & 14.825396825 \\
\hline 17 & 1.0 & 18.428571429 & 2.0 & 16.317460317 \\
\hline 18 & 1.0 & 17.825396825 & 2.0 & 16.698412698 \\
\hline 19 & 1.0 & 17.507936508 & 2.0 & 15.539682540 \\
\hline 20 & 1.0 & 16.476190476 & 2.0 & 15.730158730 \\
\hline 21 & 1.0 & 16.507936508 & 2.0 & 14.539682540 \\
\hline 22 & 1.0 & 15.825396825 & 2.0 & 14.428571429 \\
\hline 23 & 1.0 & 14.698412698 & 2.0 & 14.396825397 \\
\hline 24 & 1.0 & 14.920634921 & 2.0 & 13.317460317 \\
\hline 25 & 1.0 & 14.238095238 & 2.0 & 13.174603175 \\
\hline 26 & 1.0 & 13.222222222 & 2.0 & 15.841269841 \\
\hline 27 & 1.0 & 12.380952381 & 2.0 & 15.888888889 \\
\hline 28 & 1.0 & 12.238095238 & 2.0 & 15.349206349 \\
\hline 29 & 1.0 & 11.888888889 & 2.0 & 15.682539683 \\
\hline 30 & 1.0 & 12.523809524 & 2.0 & 13.365079365 \\
\hline 31 & 1.0 & 11.825396825 & 2.0 & 13.714285714 \\
\hline 32 & 1.0 & 11.968253968 & 2.0 & 12.587301587 \\
\hline 33 & 1.0 & 11.190476190 & 2.0 & 13.984126984 \\
\hline 34 & 1.0 & 10.873015873 & 2.0 & 13.793650794 \\
\hline 35 & 1.0 & 10.253968254 & 2.0 & 13.317460317 \\
\hline & & & & \\
\hline
\end{tabular}

\begin{tabular}{|c|c|c|c|c|}
\hline 36 & 1.0 & 9.841269841 & 2.0 & 12.634920635 \\
\hline 37 & 1.0 & 10.112716304 & 2.0 & 12.049531672 \\
\hline 38 & 1.0 & 9.603174603 & 2.0 & 11.555555556 \\
\hline 39 & 1.0 & 9.444444444 & 2.0 & 11.634920635 \\
\hline 40 & 1.0 & 8.968253968 & 2.0 & 12.190476190 \\
\hline 41 & 1.0 & 8.920634921 & 2.0 & 11.714285714 \\
\hline 42 & 1.0 & 8.936507937 & 2.0 & 11.333333333 \\
\hline 43 & 1.0 & 9.365079365 & 2.0 & 11.349206349 \\
\hline 44 & 1.0 & 8.560991105 & 2.0 & 11.372299873 \\
\hline 45 & 1.0 & 8.507936508 & 2.0 & 10.761904762 \\
\hline 46 & 1.0 & 8.047619048 & 2.0 & 11.015873016 \\
\hline 47 & 1.0 & 8.507936508 & 2.0 & 10.333333333 \\
\hline 48 & 1.0 & 8.238095238 & 2.0 & 57142857 \\
\hline 49 & 1.0 & 7.682539683 & 2.0 & 10.555555556 \\
\hline 50 & 1.0 & 7.349206349 & 2.0 & 11.031746032 \\
\hline 51 & 1.0 & 7.317460317 & 2.0 & 10.682539683 \\
\hline 52 & 1.0 & 7.047619048 & 2.0 & 10.190476190 \\
\hline 53 & 1.0 & 7.174603175 & 2.0 & 9.888888889 \\
\hline 54 & 1.0 & 6.793650794 & 2.0 & 10.111111111 \\
\hline 55 & 1.0 & 6.984126984 & 2.0 & 10.253968254 \\
\hline 56 & 1.0 & 6.746031746 & 2.0 & 10.015873016 \\
\hline
\end{tabular}

Table 2: Experimental Critical Values Obtained

\section{Critical Values Trend Analyses- Metric Max_R.}

\subsection{General Procedure Adopted.}

The tabulated data for each Max_R CV is plotted on gnuplot. Graphical analyses are conducted, general observations are reported, and various equations of fit are tried. Assistance from smooth bezier plot is retained here. In conclusion, for two CVs choice of best fit is based on flat values and for remaining two CVs, it is based on least reduced chi-square and most acceptable extendability produced at node numbers 80, 100 and 120. Lastly, the values of parameters for each equation corresponding to Max_R CV, is recorded.

\subsection{Trend Analysis - Max $R$ CV1.}

Here, the value stays at 1.0 throughout, i.e. predicted value for any node number stays at 1.0.

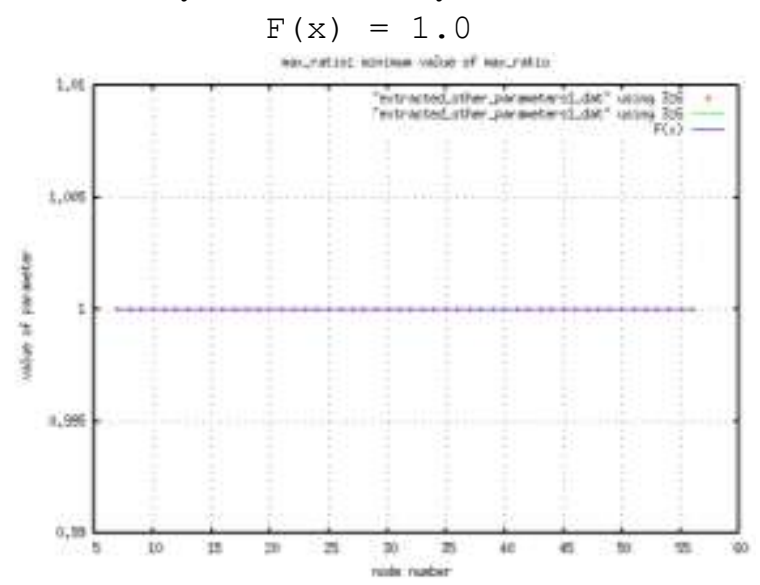

Figure 1: Max_R Critical Value 1 
Proc. of the Seventh International Conference On Advances in Computing, Electronics and Electrical Technology - CEET 2017. Copyright $(C$ Institute of Research Engineers and Doctors. All rights reserved. ISBN: 978-1-63248-126-9 doi: 10.15224/ 978-1-63248-126-9-25

\subsection{Trend Analysis - Max R CV2.}

The curve obtained here is mostly decreasing at a decreasing rate.

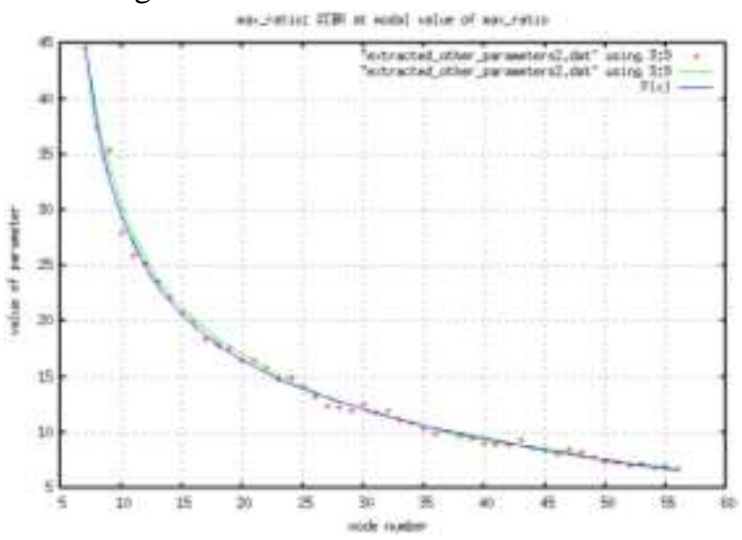

Figure 2: Max_R Critical Value 2

The potentially applicable equations are:

$$
\begin{array}{ll}
\text { 1. } F(x)=\left(a * x^{2}+f\right. & ) /(\exp ((b * x)+C)+d) \\
\text { Ch_sq }=0.383382 & F(80)=3.015871542 \\
F(100)=1.473254535 & F(120)=0.673579251 \\
\text { 2. } F(x)=\left(a * x^{1.5}+f\right) /(\exp ((b * x)+C)+d) \\
\text { Ch_sq }=0.340667 & F(80)=3.498411642 \\
F(100)=1.993015807 & F(120)=1.092042496 \\
\text { 3. } F(x)=\left(a^{*} x^{1.75}+f\right) /\left(\exp \left(\left(b^{*} x\right)+C\right)+d\right) \\
\text { Ch_sq }=0.357927 & F(80)=3.258922343 \\
F(100)=1.723910529 & F(120)=0.865100843 \\
\text { 4. } F(x)=\left(a^{*} x^{g}+f\right) /(\exp ((b * x)+C)+d) \\
\text { Ch_sq }=0.332881 & F(80)=3.898476223 \\
F(100)=2.487060843 & F(120)=1.561797634
\end{array}
$$

\section{Choice of best fit for Max_R Critical Value 2}

The equation in part 4 above has been selected because of smallest reduced chi-square value obtained and good extendability. The parameters obtained for best fit are:

$\mathrm{a}=2.58598, \mathrm{~b}=0.0312699, \mathrm{c}=2.00709, \mathrm{~d}=-8.112$ $82, \mathrm{f}=30.1444, \mathrm{~g}=1.07881$

\subsection{Trend Analysis - Max_R CV3.}

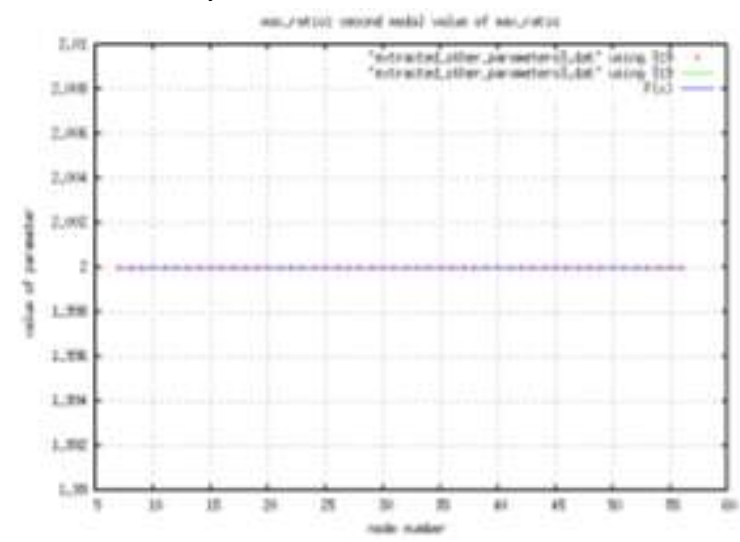

Figure 3: Max_R Critical Value 3

In the plots here, the value of this critical value has remained at 2.0 throughout.

$$
F(x)=2.0
$$

\subsection{Trend Analysis - Max $R$ CV4.}

Here the plots depict a decreasing tendency.

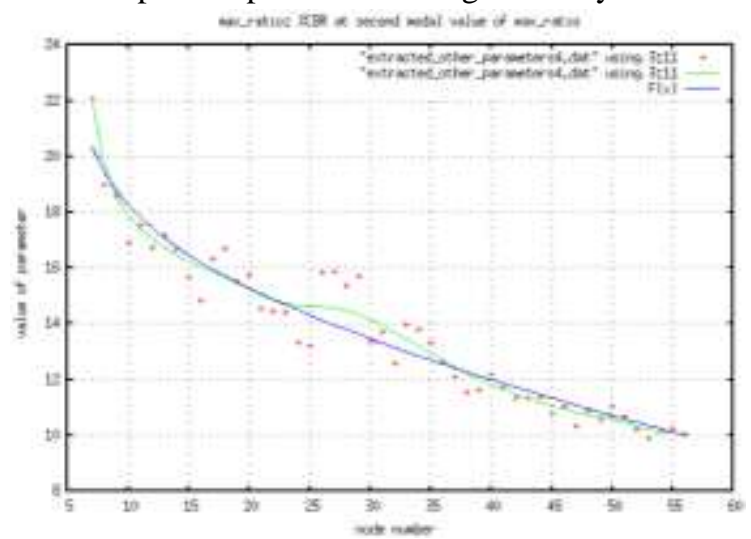

Figure 4: Max_R Critical Value 4

The potentially applicable equations are:

$$
\begin{array}{cl}
\text { 1. } F(x)=d * x+f & \\
\text { Ch_sq }=0.93645 & F(80)=4.891736389 \\
F(100)=1.264742681 & F(120)=-2.362251026 \\
\text { 2. } F(x)=(a * x) /(\exp ((b * x)+c)+d) \\
\text { Ch_sq }=0.6878 & F(80)=7.584790751 \\
F(100)=5.971593883 & F(120)=4.661296004 \\
\text { 3. } F(x)=(a * x+f) /(\exp ((b * x)+c)+d) \\
\text { Ch_sq }=0.689756 & F(80)=7.592457650 \\
F(100)=5.973639731 & F(120)=4.658560137
\end{array}
$$

\section{Choice of best fit for Max_R Critical Value 4}

The equation in part 2 above has been selected because of smallest reduced chi-square value obtained and good extendability. The parameters obtained for best fit are:

$\mathrm{a}=0.326577, \mathrm{~b}=0.0186344, \mathrm{c}=0.00936422, \mathrm{~d}=$ 1.03765

\section{Conclusion.}

This piece of probing was intended to identify some critical values applicable to metric Max_R and study their corresponding trends over varying node densities in a MANET topography of $300 \times 300 \mathrm{~m}^{2}$. The models elaborated here comprise of mathematical equations of varying complexity levels. These output will reinforce the existing tools, for more prosperous studies of MANETs for ubicomp environment as viewed by software engineers. These output can discerningly be implemented in computational algorithms to produce more realistic simulation schemes with the advantage of which novel communication protocols and middleware components devised for ubicomp may be more integrally tested.

The experiments were executed in NS-2 over Linux. The plottings and "Fit" attempts were conducted in 
gnuplot. Best fit was selected based on flat values for two critical values and on a combination of least reduced chi-square values and best extendability of equations observed at higher node numbers. Assumptions expounded in previous papers $[20,36]$ are sustained in this paper also.

This work remains a follow-up of previous endeavours $[1-13,20,36]$ and subsists as a subject for future polishing. One such task identified is the formulation of predictability for metric Max_R and its trend.

\section{References}

[1] M. Kaleem GALAMALI, Assoc. Prof Nawaz MOHAMUDALLY, Towards Dependable Pervasive Systems-A Position and Vision Paper, CEET 2014

[2] M. Kaleem GALAMALI, Assoc. Prof Nawaz MOHAMUDALLY, Model of Energy Savings achievable with Location-aware Node-to-Node Transmission in UbiComp , CEET 2014

[3] M. Kaleem GALAMALI, Assoc. Prof Nawaz MOHAMUDALLY, Model of Energy Savings achievable with Location-aware Node-to-Node Transmission in UbiComp Using Location Refresh Intervals, CEET 2014

[4] M. Kaleem GALAMALI, Assoc. Prof Nawaz MOHAMUDALLY, Model of Energy Savings achievable with Location-aware Transmission in UbiComp Using Relays, CEET 2014

[5] M. Kaleem GALAMALI, Assoc. Prof Nawaz MOHAMUDALLY, Mathematical modeling of need of exact number of relays to ensure seamless mobility in mobile computing, CEET 2014

[6] M. Kaleem GALAMALI, Assoc. Prof Nawaz MOHAMUDALLY, Modelling of need for multiple relays for ensuring seamless mobility, CEET 2014

[7] M. Kaleem GALAMALI, Assoc. Prof Nawaz MOHAMUDALLY, Investigation of prominence of placements of relays in a ubicomp topography,

[8] M. Kaleem GALAMALI, Assoc. Prof Nawaz MOHAMUDALLY, Model of energy savings achievable with location-aware transmission in ubicomp using optimised number of relays.

[9] M. Kaleem GALAMALI, Assoc. Prof Nawaz MOHAMUDALLY, Investigation of Prominence of Placements of Optimised Number of Relays in a Ubicomp Topography using Location-Aware Transmission, CEET 2015.

[10] M. Kaleem GALAMALI, Assoc. Prof Nawaz MOHAMUDALLY, Extending Node Battery Availability in Ubicomp with Location-Aware Transmission, CEET 2015.

[11] M. Kaleem GALAMALI, Assoc. Prof Nawaz MOHAMUDALLY, Extending Node Battery Availability in Ubicomp with Location-Aware Transmission using Location Refresh Intervals, CEET 2015.

[12] M. Kaleem GALAMALI, Assoc. Prof Nawaz MOHAMUDALLY, Extending Node Battery Availability in Ubicomp with Location-Aware Transmission using Uniformly Placed Relays, CEET 2015.

[13] M. Kaleem GALAMALI, Assoc. Prof Nawaz MOHAMUDALLY, Extending Node Battery Availability in Ubicomp with Location-Aware Transmission Using Optimally Placed Relays, CEET 2015.

[14] M. Kaleem GALAMALI, Assoc. Prof Nawaz MOHAMUDALLY, Model of Sender Node Energy Savings Achievable with Location-Aware MANET Transmission in Ubicomp. ACCN 2016

[15] M. Kaleem GALAMALI, Assoc. Prof Nawaz MOHAMUDALLY, Model of Overall Node Energy Savings Achievable with Location-Aware MANET Transmission in Ubicomp. ACCN 2016
[16] M. Kaleem GALAMALI, Assoc. Prof Nawaz MOHAMUDALLY, Model of Sender Node Extra Energy Savings Achievable in MANET Against Direct Node-toNode Transmission Using Location-Aware Transmission in Ubicomp. ACCN 2016

[17] M. Kaleem GALAMALI, Assoc. Prof Nawaz MOHAMUDALLY, Model of Overall Node Extra Energy Savings Achievable in MANET against Direct Node-toNode Transmission Using Location-Aware Transmission in Ubicomp. ACCN 2016

[18] M. Kaleem GALAMALI, Assoc. Prof Nawaz MOHAMUDALLY, Model of Energy Consumption Ratio Achievable in MANET Using Location-Aware Transmission in Ubicomp. ACCN 2016

[19] M. Kaleem GALAMALI, Assoc. Prof Nawaz MOHAMUDALLY, Model of Minimum Energy Consumption Ratio Achievable in MANET Using LocationAware Transmission in Ubicomp. ACCN 2016

[20] M. Kaleem GALAMALI, Assoc. Prof Nawaz MOHAMUDALLY, Model of Maximum Energy Consumption Ratio Achievable in MANET Using LocationAware Transmission in Ubicomp. ACCN 2016

[21] M. Kaleem GALAMALI, Assoc. Prof Nawaz MOHAMUDALLY, Model of Overall Energy Consumption Fairness Ratio Achievable in MANET Using LocationAware Transmission in Ubicomp. ACCN 2016

[22] M. Kaleem GALAMALI, Assoc. Prof Nawaz MOHAMUDALLY, Model of Overall Energy Consumption Fairness Proportion Achievable in MANET Using LocationAware Transmission for Ubicomp, CEET 2016

[23] M. Kaleem GALAMALI, Assoc. Prof Nawaz MOHAMUDALLY, Model of Minimum Fairness Proportion Achievable in MANET Using Location-Aware Transmission for Ubicomp, CEET 2016

[24] M. Kaleem GALAMALI, Assoc. Prof Nawaz MOHAMUDALLY, Model of Maximum Fairness Proportion Achievable in MANET Using Location-Aware Transmission for Ubicomp, CEET 2016

[25] M. Kaleem GALAMALI, Assoc. Prof Nawaz MOHAMUDALLY, Model of Sender Fairness Proportion Achievable in MANET Using Location-Aware Transmission for Ubicomp, CEET 2016

[26] M. Kaleem GALAMALI, Assoc. Prof Nawaz MOHAMUDALLY, Model of Distance Travelled by packets in MANETs using Location-Aware Transmission for Ubicomp, CEET 2016

[27] M. Kaleem GALAMALI, Assoc. Prof Nawaz MOHAMUDALLY, Model of Maximum CBR Distance Travelled by packets in MANETs using Location-Aware Transmission for Ubicomp, CEET 2016

[28] M. Kaleem GALAMALI, Assoc. Prof Nawaz MOHAMUDALLY, Model of Minimum CBR Distance Travelled by packets in MANETs using Location-Aware Transmission for Ubicomp, CEET 2016

[29] M. Kaleem GALAMALI, Assoc. Prof Nawaz MOHAMUDALLY, Model of Range CBR Distance Experienced by Transmissions in MANETs using LocationAware Transmission for Ubicomp, CEET 2016

[30] M. Kaleem GALAMALI, Assoc. Prof Nawaz MOHAMUDALLY, Trend Analyses of Parameters of Equations for Sender Node Energy Savings Achievable in ubicomp MANETs using Location-Aware Transmission, ACCN 2017.

[31] M. Kaleem GALAMALI, Assoc. Prof Nawaz MOHAMUDALLY, Trend Analyses of Parameters of Equations for Overall Node Energy Savings Achievable in ubicomp MANETs using Location-Aware Transmission, ACCN 2017.

[32] M. Kaleem GALAMALI, Assoc. Prof Nawaz MOHAMUDALLY, Trend Analyses of Parameters of Equations for Sender Node Extra Energy Savings Achievable in MANET against Direct Node-to-Node Location-Aware Transmission, ACCN 2017.

[33] M. Kaleem GALAMALI, Assoc. Prof Nawaz MOHAMUDALLY, Trend Analyses of Parameters of Equations for Overall Nodes Extra Energy Savings Achievable in MANET against Direct Node-to-Node Location-Aware Transmission, ACCN 2017.

[34] M. Kaleem GALAMALI, Assoc. Prof Nawaz 
MOHAMUDALLY, Trend Analyses of Parameters of Equations for Energy Consumption Ratio Achievable in Ubicomp MANET Using Location-Aware Transmission, ACCN 2017.

[35] M. Kaleem GaLAMALI, Assoc. Prof Nawaz MOHAMUDALLY, Trend Analyses of Parameters of Equations for Minimum Energy Consumption Ratio Achievable in Ubicomp MANETs Using Location-Aware Transmission, ACCN 2017.

[36] M. Kaleem GALAMALI, Assoc. Prof Nawaz MOHAMUDALLY, Trend Analyses of Parameters of Equations for Maximum Energy Consumption Ratio Achievable in Ubicomp MANETs Using Location-Aware Transmission, ACCN 2017.

[37] M. Kaleem GALAMALI, Assoc. Prof Nawaz MOHAMUDALLY, Trend Analyses of Parameters of Equations for Overall Fairness Ratio Achievable in Ubicomp MANETs Using Location-Aware Transmission, ACCN 2017

[38] M. Kaleem GaLAMALI, Assoc. Prof Nawaz MOHAMUDALLY, Trend Analyses of Parameters of Equations for Energy Consumption Fairness Proportion Achievable in Ubicomp MANETs Using Location-Aware Transmission, CEET 2017

[39] M. Kaleem GALAMALI, Assoc. Prof Nawaz MOHAMUDALLY, Trend Analyses of Parameters of Equations for Minimum Fairness Proportion Achievable in Ubicomp MANETs Using Location-Aware Transmission, CEET 2017

[40] M. Kaleem GALAMALI, Assoc. Prof Nawaz MOHAMUDALLY, Trend Analyses of Parameters of Equations for Maximum Fairness Proportion Achievable in Ubicomp MANETs Using Location-Aware Transmission, CEET 2017

[41] M. Kaleem GALAMALI, Assoc. Prof Nawaz MOHAMUDALLY, Trend Analyses of Parameters of Equations for Sender Fairness Proportion Achievable in Ubicomp MANETs Using Location-Aware Transmission, CEET 2017

[42] M. Kaleem GALAMALI, Assoc. Prof Nawaz MOHAMUDALLY, Trend Analyses of Parameters of Equations for Packets Per Distance Achievable in Ubicomp MANETs Using Location-Aware Transmission, CEET 2017

[43] M. Kaleem GALAMALI, Assoc. Prof Nawaz MOHAMUDALLY, Trend Analyses of Parameters of Equations for Maximum CBR Distance Achievable in Ubicomp MANETs Using Location-Aware Transmission, CEET 2017

[44] M. Kaleem GALAMALI, Assoc. Prof Nawaz MOHAMUDALLY, Trend Analyses of Parameters of Equations for Minimum CBR Distance Achievable in Ubicomp MANETs Using Location-Aware Transmission, CEET 2017

[45] M. Kaleem GALAMALI, Assoc. Prof Nawaz MOHAMUDALLY, Trend Analyses of Parameters of Equations for Range CBR Distance Achievable in Ubicomp MANETs Using Location-Aware Transmission, CEET 2017

[46] M. Kaleem GALAMALI, Assoc. Prof Nawaz MOHAMUDALLY, Trend Analyses of Critical Values Obtained for Sender Node Energy Savings Achievable in Ubicomp MANETs Using Location-Aware Transmission, CEET 2017

[47] M. Kaleem GALAMALI, Assoc. Prof Nawaz MOHAMUDALLY, Trend Analyses of Critical Values Obtained for Overall Node Energy Savings Achievable in Ubicomp MANETs Using Location-Aware Transmission, CEET 2017

[48] M. Kaleem GALAMALI, Assoc. Prof Nawaz MOHAMUDALLY, Trend Analyses of Critical Values Obtained for Sender Node Extra Energy Savings Achievable in Ubicomp MANET Against Direct Node-to-Node Location-Aware Transmission, CEET 2017

[49] M. Kaleem GALAMALI, Assoc. Prof Nawaz MOHAMUDALLY, Trend Analyses of Critical Values Obtained for Overall Nodes Extra Energy Savings Achievable in Ubicomp MANET Against Direct Node-toNode Location-Aware Transmission, CEET 2017

[50] M. Kaleem GALAMALI, Assoc. Prof Nawaz MOHAMUDALLY, Trend Analyses of Critical Values
Obtained for Energy Consumption Ratio Achievable in Ubicomp MANETs Using Location-Aware Transmission Strategies, CEET 2017

[51] M. Kaleem GALAMALI, Assoc. Prof Nawaz MOHAMUDALLY, Trend Analyses of Critical Values Obtained for Minimum Energy Consumption Ratio Achievable in Ubicomp MANETs Using Location-Aware Transmission Strategies, CEET 2017

[52] Markus Bylund and Zary Segall, Towards seamless mobility with personal servers, 2004.

[53] Masugi Inoue, Mikio Hasegawa, Nobuo Ryoki and Hiroyuki Morikawa, Context-Based Seamless Network and Application Control, 2004

[54] Xiang Song, Umakishore Ramachandran, MobiGo: A Middleware for Seamless Mobility, College of Computing Georgia Institute of Technology, Atlanta, GA, USA, August 2007

[55] Budzisz, Ferrús, R., Brunstrom A., Grinnemo, K, Fracchia R., Galante, G., and Casadevall, F. Towards transport-layer mobility: Evolution of SCTP multihoming, March 2008

[56] Paul Dourish \& Genevieve Bell, Divining a digital future, 2011

[57] Xiang Song, Seamless Mobility In Ubiquitous Computing Environments, PhD Thesis, Georgia Institute of Technology, August 2008

[58] Kevin O Mahony, Jian Liang, Kieran Delaney, User-Centric Personalization and Autonomous Reconfiguration Across Ubiquitous Computing Environments, NIMBUS Centre Cork Institute of Technology, Cork, Ireland, UBICOMM 2012

[59] Pablo Vidales, Seamless mobility in 4G systems, Technical Report, University of Cambridge, Computer Laboratory, Number 656, November 2005

[60] João Pedro Sousa and David Garlan, Aura: An Architectural Framework for User Mobility in Ubiquitous Computing Environments, School of Computer Science, Carnegie Mellon University, USA, August 2002

[61] Dennis Lupiana, Ciaran O'Driscoll, Fredrick Mtenzi, Defining Smart Space in the Context of Ubiquitous Computing, Dublin Institute of Technology, Ireland, Special Issue on ICIT 2009 Conference - Web and Agent Systems, 2009

[62] N.S.V.Shet1, Prof.K.Chandrasekaran2 and Prof. K.C.Shet3, WAP Based Seamless Roaming In Urban Environment with Wise Handoff Technique, International Journal of UbiComp (IJU), Vol.1, No.4, October 2010

[63] Yipeng Yu Dan He Weidong Hua Shijian Li Yu Q Yueming Wang Gang Pan, FlyingBuddy2: A Braincontrolled Assistant for the Handicapped, Zhejiang University, UbiComp'12, September 5-8, 2012.

[64] Jing Su, James Scott, Pan Hui, Jon Crowcroft, Eyal de Lara Christophe Diot, Ashvin Goel, Meng How Lim, and Eben Upton, Haggle: Seamless Networking for Mobile Applications, 2007

[65] Rui Han, Moustafa M. Ghanem, Li Guo, Yike Guo*, Michelle Osmond, Enabling cost-aware and adaptive elasticity of multi-tier cloud applications, Future Generation Computer Systems, 2012

[66] Byrav Ramamurthy, K. K. Ramakrishnan, Rakesh K. Sinha, Cost and Reliability Considerations in Designing the NextGeneration IP over WDM Backbone Networks, 2012.

[67] Bhavish Aggarwal, Aditya Akella, Ashok Anand, Athula Balachandran, Pushkar Chitnis, Chitra Muthukrishnan, Ram Ramjee and George Varghese, EndRE: An End-System Redundancy Elimination Service for Enterprises, NSDI 2010, San Jose, CA

[68] Ashok Anand, Vyas Sekar and Aditya Akella, SmartRE: An Architecture for Coordinated Network-wide Redundancy Elimination, SIGCOMM 2009, Barcelona, Spain

[69] John Breeden II, "Smart-phone battery life could double without better batteries", Nov 14, 2012

[70] Andy Boxall, "When will your phone battery last as long as your kindle", December 5, 2012

[71] Imielinski, T. and Navas, J.C. (1999). GPS-based geographic addressing, routing, and resource discovery. Comms. ACM, Vol. 42, No. 4, pp. 86-92.

[72] Hightower, J. and Borriello, G. (2001). Location Systems for Ubiquitous Computing. IEEE Computer, Vol. 34, No. 8, August, pp. 57-66. 
[73] Harter, A., Hopper, A., Steggles, P., Ward, A. and Webster, P. (2002). The Anatomy of a Context-Aware Application. Wireless Networks, Vol. 8, No. 2-3, Mar-May, pp. 187-197.

[74] Hightower, J., Brumitt, B. and Borriello, G. (2002). The Location Stack: A Layered Model for Location in Ubiquitous Computing. Proceedings of the 4th IEEE Workshop on Mobile Computing Systems \& Applications (WMCSA 2002), Callicoon, NY, USA, June, pp. 22-28.

[75] Graumann, D., Lara, W., Hightower, J. and Borriello, G. (2003). Real-world implementation of the Location Stack: The Universal Location Framework. Proceedings of the 5th IEEE Workshop on Mobile Computing Systems \& Applications (WMCSA 2003), Monterey, CA, USA, October, pp. 122-128.

[76] Ko, Y., \& Vaidya, N. H. (2000). Location-aided routing (LAR) in mobile ad hoc networks. Wireless Networks, 6(4), 307-321.

[77] Liao, W.-H., Tseng, Y.-C., \& Sheu, J.-P. (2001). GRID: a fully location-aware routing protocol for mobile ad hoc networks. Telecommunication Systems, 18(1), 37-60.

[78] Kuhn, F., Wattenhofer, R., Zhang, Y., \& Zollinger, A. (2003). Geometric ad-hoc routing: of theory and practice. In Proceedings of the ACM (PODC'03) (pp. 63-72).

[79] Jiang, X., \& Camp, T. (2002). Review of geocasting protocols for a mobile ad hoc network. In Proceedings of the Grace Hopper Celebration (GHC).

[80] Ko, Y. \& Vaidya, N. H. (1999). Geocasting in mobile ad hoc networks: location-based multicast algorithms. In Proceedings of the IEEE (WMCSA '99) (pp. 101).

[81] Mauve, M., Fuler, H., Widmer, J., \& Lang, T. (2003). Position-based multicast routing for mobile ad-hoc networks (Technical Report TR-03-004). Department of Computer Science, University of Mannheim.

[82] Xu, Y., Heidemann, J., \& Estrin, D. (2001). Geographyinformed energy conservation for adhoc routing. In Proceedings of the ACM/IEEE (MOBICOM'01) (pp. 70-84).

[83] Hu, Y.-C., Perrig, A., \& Johnson, D. (2003). Packet leashes: a defense against wormhole attacks in wireless ad hoc networks. In Proceedings of the INFOCOM' 03 (pp. 19761986).

[84] Patwari, N., Hero III, A. O., Perkins, M., Correal, N. S., \& O'Dea, R. J. (2003). Relative location estimation in wireless sensor networks. IEEE Transactions on Signal Processing, 51(8), 2137-2148.

[85] Baldauf, M., Dustdar, S., \& Rosenberg, F. (2007). A Survey on Context Aware Systems. International Journal of Ad Hoc and Ubiquitous Computing, Inderscience Publishers. forthcoming. Pre-print from: http://www.vitalab.tuwien.ac.at/ florian/papers/ijahuc2007.pdf

[86] Hong, D., Chiu, D.K.W., \& Shen, V.Y. (2005). Requirements elicitation for the design of context-aware applications in a ubiquitous environment. In Proceedings of ICEC'05 (pp. 590-596).

[87] Neeraj Tantubay, Dinesh Ratan Gautam and Mukesh Kumar Dhariwal, A Review of Power Conservation in Wireless Mobile Ad hoc Network (MANET)", International Journal of computer Science Issues, Vol 8, Issue 4, No 1, July 2011.

[88] Wenrui Zhao, Mostafa Ammar and Ellen Zegura, "A Message Ferrying Approach for Data Delivery in Sparse Mobile Ad Hoc Networks", MobiHoc'04, May 24-26, 2004, Roppongi, Japan.

[89] Sgroi et al., "Designing Wireless Protocols: Methodology and Applications, February 2000.

[90] Gyula et al., "Simulation-based optimization of communication protocols for large-scale wireless sensor networks", 10 October 2002

[91] Rao and Sharma, "Cross Layer Protocols For Multimedia Transmission in Wireless Networks", June 2012

[92] Herms et al, "Realism in Design and Evaluation of Wireless Routing Protocols", 2007.
About Author (s):

Associate Professor Nawaz Mohamudally works at University of Technology, Mauritius (UTM) and has undertaken supervision of MPhil/PhD Students for many years.

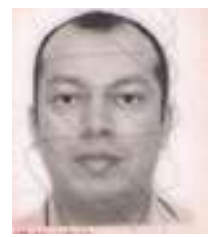

M. Kaleem Galamali is a part-time student (achieved M Phil Transfer on 28.10.2014, currently $\mathrm{PhD}$ student) at UTM under supervision of A.P. Nawaz Mohamudally. 